\title{
Climate report cuts call for strong policies
}

London. The conclusions of a United Nations scientific document distilling the latest research on climate change appear to have been watered down to meet criticisms from both oil-exporting countries and the US government, which had suggested the document was too prescriptive in its proposals for future action.

The original 22-page draft document, based on the 3,600-page Second Assessment Report from all three working groups of the Intergovernmental Panel on Climate Change (IPCC), called for "strong policy measures" to limit and reduce greenhouse gas emissions.

But this phrase has been cut, as well as a whole paragraph setting out options through which countries can reduce greenhouse gas emissions. The new, 28-page final 'synthesis document' was approved last Friday at the end of a five-day meeting in Rome. Section eight of the document - called The Road Forward - its concluding segment, has been totally rewritten. Its final wording was strongly influenced by the United States.

Environmentalist groups say that they are satisfied with the overall thrust of the document. But they are unhappy at the removal of references to the need for strong policy measures. "The United States was unhelpful in this area," says Bill Hare, climate policy adviser for Greenpeace.

Bob Watson, associate director of the US Office of Science and Technology Policy, and co-chair of IPCC Working Group Two, which deals with the impact of climate change and possible responses to it, says the changes were necessary. The original draft was much too long. "We made some suggestions to shorten it and make it less prescriptive," he says.

Watson says that an IPCC document always treads a fine line. "It will never be a smooth document when more than 100 countries are helping to write it. I can understand that some non-governmental organizations may not like the final version. But the draft version seemed to tell governments what to do. That is the role of the climate convention and its subsidiary bodies."

But Watson's view is challenged by Irving Mintzer, a senior research scholar at the Center for Global Change in Maryland. Mintzer, a lead author on Working Group Three - but not a member of the synthesis report's drafting team - denies that the team tried to "manipulate governments". The original section eight, he says, "pointed out what governments could do, but in a way that would advance national economic development priorities".
The new version does not mention nine possible "policies and instruments", contained in the original draft, through which countries could reduce greenhouse gas emissions. These included carbon taxes, deposit refund systems, subsidies, product bans and tradeable permits - where a country with high costs of reducing greenhouse gas emissions invests in emissionreducing measures in a country with lower reduction costs, but is credited for emission reductions in its own climate gas 'account'.

The original opening sentence in section eight stated that "future climate change will be determined primarily by the atmospheric concentration of carbon dioxide". This has also been deleted. A new sentence, inserted at the top of the second paragraph, states merely that "uncertainties remain" in the judgement of "what constitutes dangerous anthropogenic interference with the climate system".

A related paragraph that mentioned that carbon dioxide emissions needed to be stabilized at close to twice the pre-industrial levels "within a few decades" was also changed, with references to timescales taken out. Oil-producing countries have argued for longer and phased reduction of greenhouse gases to cushion the potential loss of oil export revenues.

Ehsan Masood

\section{BSE results 'may quell panic', but caution still needed}

London. Representatives of Britain's meat industry were expressing cautious optimism at the beginning of this week that new scientific data suggesting a lack of human susceptibility to bovine spongiform encephalopathy (BSE) - known as 'mad cow disease' - will help to stem a public panic that has seen beef sales fall by about 20 per cent in recent weeks.

"If it is true, it is obviously good news for industry," a spokesman for the Meat and Livestock Commission, the main industry trade body, said last Monday, 18 December. "From our point of view, anything which confirms what we have been telling the press for the past six weeks is very welcome."

The new data are contained in a paper published in today's Nature (see pages 779 and 761), and are based on work carried out by a team headed by John Collinge at $\mathrm{St}$ Mary's Hospital in London. An embargo on the results was lifted on Monday after reports on the research had appeared in the press the previous day.

The reported research shows that mice that had been genetically manipulated to react to the agent that causes CreutzfeldtJakob disease (CJD) in humans remained healthy when injected with the agent responsible for BSE. Collinge himself emphasizes that the findings only represent the "first stage" in an overall experiment. The results reported so far cover only a comparison of initial survival rates between mice injected with CJD and BSE, while the full study, including evidence on the eventual mortality rates of the mice exposed to BSE - and which remain healthy - could take up to two years.

Indeed, there is some disagreement in the research community as to whether the initial data should have been published at this stage, without awaiting the results of the full study. "I think it is premature, both scientifically and politically," says John Bourne,

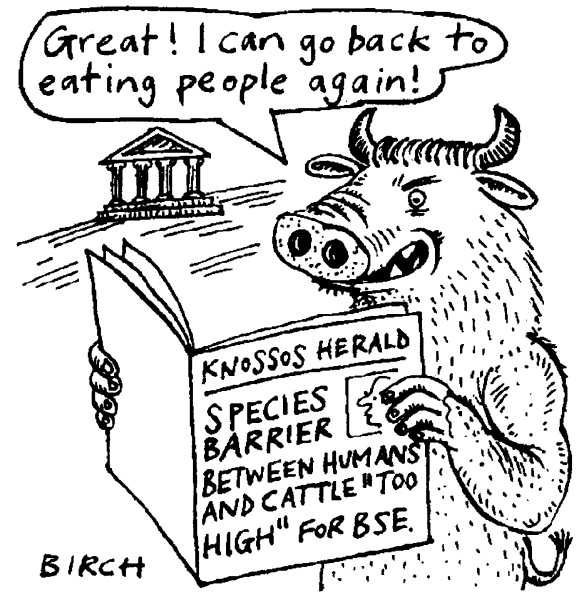

director of the Biotechnology and Biological Science Research Council's Institute for Animal Health. "None of this work has given us positive evidence [of the relationship between BSE and CJD] either way."

But Collinge himself claims that it would have been "unrealistic" to have awaited the full results of the study, given the significance of the results.

Indeed, some of those who have recently made public their own concern about a possible link between BSE and CJD say that they have been reassured by Collinge's results. Colin Blakemore, for example, Waynflete Professor of Physiology at the University of Oxford, who two weeks ago wrote an article advising people to give up eating beef "until the picture is clearer", described Collinge's work on Monday as "a very significant piece of evidence", and added "of course, I've changed my mind".

Blakemore says his earlier warning was based on the earlier lack of sufficient evidence to justify categorical statements from Stephen Dorrell, the health minister, that there was no evidence of a risk of contracting CJD from eating beef. "What I wanted was more caution - and more science," says Blakemore, adding that "[we] still need more results, and more epidemiological evidence; we must not relax our regulations". $\square$ 